\title{
PHYTOVIRUS MONITORING AT THE POTATO FIELDS IN CHERNIHIV REGION AGROCENOSES
}

\section{O. O. Dmytruk, S. V. Derevianko, L. M. Reshotko, I. V. Volkova, O. O. Kucheriavenko, T. O. Bova, Zhang Zhenghua}

Among various diseases of potatoes viral ones are widespread with a tendency towards increasing of their harm in the main regions of potato cultivation in many varieties that are in economic and trade turnover. Fifty three viruses of 22 families which differ in morphological, physical, biological and immunological properties have been described in the culture; about 30 of which are important in the global potato farming. However, the species composition of pathogens and the degree of infestation of planting vary depending on natural and economic conditions, varieties of potato and state of seed farming.

Under natural conditions of Ukraine potato virus $\mathrm{M}$, potato virus $\mathrm{Y}$, potato virus $\mathrm{S}$, potato virus X, potato leafroll virus are widespread. Enrichment of population with new to the region harmful viruses and their strains was established. Along with common ones, necrotic strains of potato virus $\mathrm{Y}$ become more widespread; strain causing the formation of the bulb ring necrosis $\left(\mathrm{PVY}^{\mathrm{NTN}}\right)$ was found. Pathogens, carriers of which are ground parasitic nematodes and fungi that cause damage to the bulbs, which reduces their marketability and suitability for food consumption and industrial processing: tobacco rattle virus (TRV), potato mop top virus (PMTV), potato spindle tuber viroid (PSTV) were identified.

Unlike other pathogens, virus in the infected the plant remains throughout its life, and also in its vegetative progeny that results in the accumulation of viruses in crops and seeds, as well as agrocenoses. Under the scheme of manufacturing of certified seed potatoes of the European Plant Protection Organization, the following viruses has been specified for testing: basic potato virus A, M, S, X, Y, potato leafroll virus (PLV) and others - alfalfa mosaic virus (AMV), cucumber mosaic virus (CMV), potato aucuba mosaic virus (PAMV), PMTV, tobacco mosaic virus (TMV), TRV, tomato black ringspot virus (TBRV), tomato spotted wilt virus (TSWV) [3].

Harm of viral diseases of plants appears to reduce the yield of plants, deteriorate product marketability and quality. Yield losses due to viral lesions depend on the species and strains of pathogens common in this soil and climatic zone. Yield losses of potatoes in Polissia of Ukraine due to viral diseases are on average 30-40\%, reaching 38-70\%. Lesions from the virus $\mathrm{M}$ in Polissia may constitute more than $40 \%$ of the crop, growing under complex involvement of plants with several pathogens. In this zone, most of varieties are completely infected with virus 
$\mathrm{M}$, and therefore the economy annually fails to receive much of the harvest. Most viruses are transmitted to bulb offspring tuberous with the efficiency of $100 \%$, excluding tobacco rattle virus and potato mop top virus - involvement of bulbs with these viruses from diseased plants ranges from $20 \%$ to $85 \%$.

Performance of potato farming is determined, above all, by the perfection of infection control system used in seed farming. It is shown that propagation of recovered material in conditions that do not provide complete protection of plants against viral reinfection leads to rapid accumulation of viruses and reduction of varietal and sowing qualities of seed potatoes. The rate of growth of viral infection is largely determined by the susceptibility of varieties to certain viruses and their complexes as well as by the level of infection load in the manufacturing places.

Thus, the urgency of phytoviruses prevalence in the environment has both fundamental and practical value. Knowledge of species composition of pathogens and their vectors in a particular area, pathways of infection spreading in the field, factors that contribute to the involvement of plants and manifestation of disease signs or are limiting factors for infection, allows to predict the emergence and development of viral diseases and is the basis for proper selection and effective application of protective measures.

Materials and methods. A survey of potato planting was conducted according to the current guidelines. Accounting and sampling for laboratory analysis was conducted in budding to flowering phase of potato plants using diagonal sampling method. For virological study, 3-4 leaves of the upper and middle layer were sampled from the main stem of the plant and stored at $4{ }^{\circ} \mathrm{C}$. The leaves were sampled not only from plants that have external signs of disease, but also from healthy ones, given the possibility of latent virus carriage.

Study results were expressed by the parameter of disease prevalence that was calculated by the equation:

$$
P=\frac{n}{N} \times 100
$$

where $\mathrm{P}$ - prevalence of the disease, $\%$;

$\mathrm{n}$ - number of involved plants in the sample, units;

$\mathrm{N}$ - total number of plants in the sample, units.

For the detection and identification of potato viruses, method of visual and serological diagnostic, electron microscopy of native preparations (EM), bioassay were used. Antisera for detection of potato viruses obtained in the Laboratory of Virology of the Institute of Agricultural Microbiology and Agroindustrial Manufacture of NAAS were used for serological analyses. 
Native preparations for electron microscopy were prepared by negative staining method modified in the Laboratory of Virology of the IAMAM. Preparations were studied in electron microscopes Tesla-540 (Czech Republic) and EM-125 (Ukraine) under instrumental magnification $\times 20-22$ thousand.

To clarify the nature of the disease and composition of pathological complexes under viral infection, the method of indicator plants was used. Using mechanical inoculation, with previous application of silicon carbide, virus was passed to the tobacco Nicotiana tabacum L. Tobacco and tomatoes Lycopersicon esculentum Mill. Test plants that remained asymptomatic carriers of the virus or showed symptoms of infection, local or systemic. In all the experiments, healthy not inoculated plants were used as the control. Plants were grown under conditions of growing room at a temperature of $20-22{ }^{\circ} \mathrm{C}$ with 16 hours photoperiod. Within 14-30 days after inoculation, development of symptoms was followed-up, and viral infection was controlled by immunological and electron microscopy methods.

Thus, agrocenoses of the Chernihiv region show intensive infection of potato plants with viruses, which suggests hard natural infectious background (presence of effective rezervators and vectors of potato viruses in the environment). When growing a healthy source material in the field during 2-3 years, there is a high degree of prevalence of mosaic group viruses. Therefore, determination of the risks of prevalence of phytopathogenic potato viruses based on investigation of the environmental features of the pathogen are needed for effective control of viral diseases at all stages of growing varieties (in the process of recovery, in the manufacture of seed material, its certification, carrying out assessment of selective samples). For this purpose it is required to use not only visual assessment of crops but also to use laboratory methods for diagnostics of potato viruses.

In order to improve the level of phytosanitary safety and obtain high-quality seed material, it is required to carry out primary seed farming in the protected ground and use recovered varieties of potatoes and meet effective methods of protecting plants against viruses. When growing potatoes in the field, it is required to use recovered seed potatoes and follow technology that ensures avoidance of viral transmission from rezervators. 